\title{
Soft Factor In the Implementation of Quality Management Program in Majlis Agama Islam Selangor (MAIS)
}

\author{
Musaiyadah Ahmadun, Siti Arni Basir*, Osman Md Rasip \\ Academy of Islamic Studies, University of Malaya, 50603, Kuala Lumpur \\ *Corresponding author: sitiarni @um.edu.my
}

Article history: Received: 26 October 2017 Received in revised form: 22 April 2018 Accepted: 1 August 2018 Published online: 31 August 2018

\begin{abstract}
Many studies on the implementation of quality management programs were carried out by previous researchers. However, the study on the soft or human factors in the implementation of quality management programs is still poorly explored. Therefore, this article aims to analyze soft factors in the implementation of quality management programs at Selangor Islamic Religious Council or Majlis Agama Islam Selangor (MAIS). This study uses a qualitative method involving MAIS as a case study. Semi-structured interviews were used as a data collection method and supported by relevant documents collected from MAIS. A total of fifteen informants comprising top management and MAIS officers were interviewed to obtain in-depth information on the subjects studied. The findings reveal that there are six soft factors emerged in the implementation of quality management programs at MAIS namely leadership, training and development, teamwork, customer focus, Syura and rewards. This study demonstrates that soft factors has helped facilitate the implementation of quality management programs in MAIS. The results of this study can be used as guidance by managers in public or corporate organizatons in their efforts to implement quality management programs effectively.
\end{abstract}

Keywords: Soft factor; implementation; quality management; majlis agama islam selangor; qualitative

\begin{abstract}
Abstrak
Kajian mengenai pelaksanaan program pengurusan kualiti telah banyak dijalankan oleh pengkaji-pengkaji lepas. Namun, kajian mengenai faktor insaniah dalam pelaksanaan program pengurusan kualiti masih kurang diterokai. Artikel ini bertujuan untuk menganalisis faktor-faktor Insaniah dalam pelaksanaan program pengurusan kualiti di Majlis Agama Islam Selangor (MAIS). Kajian ini menggunakan kaedah kualitatif yang melibatkan Majlis Agama Islam Selangor (MAIS) sebagai kajian kes. Temu bual separa-struktur digunakan sebagai kaedah pungutan data dan disokong dengan penelitian dokumen-dokumen yang berkaitan di Majlis Agama Islam Selangor (MAIS). Seramai lima belas orang informan yang terdiri daripada pengurusan atasan dan pegawai Majlis Agama Islam Selangor (MAIS) telah ditemu bual bagi mendapatkan maklumat berkaitan tajuk yang dikaji. Hasil kajian menunjukkan bahawa terdapat enam faktor insaniah dalam pelaksanaan program pengurusan kualiti iaitu kepimpinan, latihan dan pembangunan, kerja berpasukan, fokus kepada pelanggan, Syura dan ganjaran. Kajian ini membuktikan bahawa dengan adanya faktor insaniah ia telah membantu melancarkan lagi pelaksanaan program pengurusan kualiti di MAIS. Hasil daripada kajian ini boleh dijadikan panduan oleh pihak pengurus sama ada dari sektor awam atau korporat dalam usaha mereka untuk melaksanakan program pengurusan kualiti secara efektif.
\end{abstract}

Kata kunci: Faktor insaniah; pelaksanaan; pengurusan kualiti; majlis agama islam selangor; kualitatif

(C) 2018 Penerbit UTM Press. All rights reserved

\subsection{INTRODUCTION}

Quality management has been the main agenda for organizations in achieving the aim, vision and mission (Syed Azauddin, 2005). The implementation of total quality management in an organization is needed to be able to compete at the international level. (Mohamad Sani and Mumtaz Began, t.t). Recently, awareness on the quality management has expanded and has been a common practice among many organizations. It has been proven when organizations worldwide as in Britain, United States, France, Germany, Italy, Switzerland and Sweden have strategically practice using total quality management to attract customers and achieving source of income (Oakland, 2009).

According to Sun et al. (2004), quality management is a working culture in organizations. Culture and passion in total quality management is shown through frequent improvement, by product and service offered using innovative scientific methodology. This statement was supported by Okland (2004), which according to him total quality management is not only to increase product and service quality, but also the culture that can bring changes to produce an excellent organization. Apart from that, total quality management is a culture transformation that is equipped with latest factors of behavior and values, system and procedure, operational practice and organizational structure (Oakland, 2004). 
The main aim of total quality management is to provide satisfaction to the customers. It can be done by producing output that can fulfill their needs and meet their expectation. Furthermore, every product or service output produce by organizations must be ensured to be free from defect or error. Defect or error can affect customer satisfaction. Therefore, an organization should ensure that output that is being produced should be right and accurate from the early stage as required by the customers (Roslina, 2006).

Quality management system also gives many benefits to organizations. Among the benefits are facilitating work and job procedures, improving practice based on values, promoting friendly environment, improving organizational image and making organization as reference (Hassan Al-Banna, 2015). Study conducted by Hasliza et al. (2016), shows that there are three benefits in implementation of quality management which is achieving customer's charter target, making an excellent organization and having systematic work management.

Foundation of total quality management practice can be divided into two main aspects which are soft and hard factor. Both factors are applied in supporting the efficiency in technical aspect that are always stressed on in the implementation of total quality management (Flyn et al., 1995). According to Lewis (2006a), soft factors in quality management is more focusing on the behavioral aspect and usually related to human aspects (human resources). These include training and education, loyalty, leadership, cooperation, customer satisfaction, human empowerment, relation with suppliers and professional bodies, communication, performance award and positive behaviors. On the other hand, hard factors have relationship with instruments and system as in benchmarking, quality system, innovation, performance evaluation, process control and product design or service.

Soft factor is always related to the management concept and quality principle like in leadership for empowering work culture in an organization (Vouzas \& Psyhogios, 2007; Thiagaragan et al., 2001). According to Thiagaragan et al., (2001), the element in soft factors in total quality management is actually related to the long term issues that have to be focused in accordingly. With that, soft factor have to be given serious consideration in the total quality management program to increase the efficiency in its implementation.

Literature shows that there are few studies that mentioned briefly on the soft factors in total quality management. These studies found that there were several elements that can be related to soft factors in the implementation of total quality management. Among them are leadership (Kutlu \& Kadaifci, 2014 and Nektarios, 2015), customer focus (Mosadeghrad, 2015 and Azimatun et al., 2012), teamwork (Melao \& Gamboa, 2012), reward (Hasan Al-Banna et al., 2015) and, training and development (Mohamad Asrofi \& Shahrizal, 2016).

Literature shows that soft factor is a critical aspect and studies focusing on its roles in quality management program should be implemented. Only the implementation of effective quality program can produce real benefits to an organization. By analysing and studying on the soft factor will give clear understanding to researchers, top management and quality management practitioners to understand how and why employees shows different reaction on quality programs. For example, by offering training, gratitude and rewards, employees will be more motivated which will in turn give support and cooperation in total quality management. On the other hand, lack of training and reward will cause employees to avoid quality program. Another important aspect is understanding the function of soft factor that can facilitate management to manage employees that shows discontent and against towards the implementation of total quality management in their organizations (Siti Arni et al., 2016).

Literature shows that studies on soft factors in total quality management implementation are still lacking especially in the context of Malaysia. Only Lau and Idris (2001) and Madi et al. (2008) have conducted empirical research on the soft factors. Meanwhile, other researchers have briefly discussed on the soft factors such as Yang (2006), Hoang et al. (2006), Sila and Ebrahimpour (2005) and Hafeez et al. (2006).

Above discussion shows that empirical studies on soft factor in quality program implementation are still small. Discussion also shows the negligence on soft factor can raise other issues in the implementation of quality program such as lack of support from the employees. Therefore, there is a need to conduct study on soft factor in the implementation of total quality management. This study objective is to investigate the soft factors in the implementation of total quality management in Selangor Islamic Religious Council or Majlis Agama Islam Selangor (MAIS). This study will contribute to the body of knowledge in the context of soft factors in total quality management in the management of religious body in Malaysia.

\subsection{BACKGROUND OF SELANGOR ISLAMIC RELIGIOUS BOARD (MAIS)}

MAIS is an entity incorporated according to section 5(1) enactment of Selangor state religious affair 2003. In its early inception, MAIS acted as advisor to His Highness the Sultan as allocated in section 37 administration enactment of the Islamic Law 1952 (enactment no.3, 1952). However, in the year 2003, the function of MAIS was repealed and replaced with section 6, administration enactment of Islam religion (Selangor state) 2003, where MAIS act as the main authority in state of Selangor after the Sultan.

MAIS has put the community agenda as the vision and mission to elevate the development the muslim society especially in Selangor, in line with the status achievement of the state of Selangor as a developed state in the year 2005. In materializing the big mission, the responsibilities of MAIS is perfected by thirteen proactive, planned and integrated sectors. As a state religious entity, MAIS has played a big role in ensuring the social and economic harmony of the community in Selangor. MAIS has provided few services in ensuring the economic well-being of the Selangor Muslim community. Among the initiatives is baitulmal service that covers the aspect of waqaf, property wealth, hibah and rental services.

MAIS is also a body that has a role in fulfilling the social responsibilities to Muslim in Selangor. Among the social responsibility program conducted by MAIS is helping the mualaf within the vicinity of Selangor by providing shelter home to mualaf, giving monetary and education assistance and making surveillance on their welfare. MAIS has provided a total of RM 21.2 million for the education assistance and RM 4.2 million for training development program to mualaf (MAIS, 2015). 


\subsection{LITERATURE REVIEW}

\subsection{Soft Factor in Quality Management}

Aspect of soft factors are closely related to human behaviors as in organization culture, leadership and top management commitment, human resources, customer and company shareholders (Ho et al., 2001; Prajogo and McDermott, 2005). In other words, the foundation of soft factors is based on human management, for example the roles of top management on employee's career development in an organizations (Rahman, 2001; Rahman 2004). Several academics has identified that soft factors have positive influence on the increment of quality and performance of organizations (Lau and Idris, 2001; Madi et al., 2008; Rahman and Bullock, 2005; Mora et al. 2013; Psomas et al., 2014; David \& Bishnu, 2009; Lewis et al., 2006a; Lewis et al., 2006b).

Soft factor is essential to any organizations because it help employees to understand the work culture in organizations. Besides that, soft factors like teamwork, education and training, top management commitment, continuous improvement, employee's involvement and customer's satisfaction bring positive impact on organization development, productivity, quality, competitiveness and ability development (Lau and Idris, 2001). Apart from that, quality award such as Malcolm Baldrige award, European quality award and Deming prize had also identified soft factors such as leadership, training and communication, teamwork and learning as main practices in the improvement of efficient quality program (Madi et al., 2008).

Study done by Madi et al. (2008) on electrical and electronic companies in Malaysia, shows that employee involvement was the most dominant soft factors in influencing the quality management and increment of quality in the companies. Psomas et al. (2014) also found that soft factors and hard factors applied in food industry have brought benefits in quality management, internally and externally. The study has shown that soft factors have a direct effect on the improvement of quality, staff benefits and customer satisfaction. Meanwhile, study conducted by Siti Arni et al. (2013) shows that soft factors have significant influence in the implementation of quality management system in Melaka Zakat Centre.

There is an indirect significant effect between soft and hard factors. It has been proven by Corredor and Goni (2010) where it was found that implementation of soft factors in technical aspect in organizations can give positive effects. Among the effects are increasing sales, profits in marketing and also having positive effect on firm business and stock exchange values. Furthermore, study by David and Bishnu (2009) on the quality management implemented by small and medium enterprises in Australia has founded that overall performance of quality management in small enterprises were better. This is due to the availability of soft factor in quality management. Soft factors such as employees training, skills improvement, employees and customers involvements has become the main factors in maintaining customer satisfaction and companies' competitiveness.

\subsection{Element of Soft Factor in Quality Management}

\subsubsection{Top Management Leadership}

Top management should play the roles and responsibilities in creating one culture, flow of thought, feelings and positive work method in an organization so that it can give a proper and clear understanding on quality management towards employees (Mumtaz et al., 2010). Zahrah et al., (2009) on the other hand viewed that to succeed in the challenging environment; the leaders should focus on the important issues regarding quality and competitive cost. Accordingly, leaders should give commitment on the organization excellence and always open minded towards criticism, failures and suggestions. Apart from that, leaders should shows commitment in informing employees on the importance of quality management and its functions, by setting up policies and quality objectives.

Study by Kutlu and Kadaifci (2014) found that leadership is one of the important factors in succeeding quality program implementation. While Mosadeghrad (2015) found that leadership is the main factor that contributes to the success of health institutions in Iran. Total quality management has shown to be fruitful when there is commitment and management involvement in organizations. Total quality management program can improve the product quality and increase the service effectiveness, which in turn will increase customer satisfaction when the management are involve totally in the organization. Leadership support on quality management activities will produce a conducive environment, competitiveness and continuous improvement (Nicholas et al., 2014). This can be proved from the study conducted by Nektarios (2015), where top management involvements has given a huge impact on the quality development in organization at various sector and also able to increase financial and profit performance. Top management issues in quality management have been studied by previous researchers, but the issue is seen from a success factor perspective. Past studies do not examine top management leadership from a soft factor perspective.

\subsubsection{Syura}

Syura is an Arabic word which exactly means consultation. To understand the exact meaning of Syura, it is essential to know about Shara, Yusharu and Mushawarah which means to show thing (Mohd Johdi, 2014). Besides that, Jabr (2009) explain that Shawara its means consult, Yusharu means he consulted him or discuss with somebody to find out his opinion. While the Mushawarah means, a good counsel or consultations. Furthermore, Caterina Aiena (2014) said, Syura is the consultative principle present in Islam since the time of the prophet, authenticated by the Quran and Sunnah. Even if not systematically organized, originally the concept of Syura ranked high in the activities of the first for caliphs of the Rasheedun caliphate and represented a key element in the decision making.

Syed Othman al-Habshi (1998) and Abdullah (2002) suggested that Syura is not only a consultation, but a place where members can give opinions based on one expertise and also deciding on the best decision. Among the method in implementing Syura is by holding discussion and meeting. Therefore, the basic principle of Syura that must be available in an organization is that everyone making the decision must be in one voice by giving the opportunity for everyone to give ideas before the final decision is taken (Muhammad Mustakim et al. 2015)

The Muslim community that practice Syura or meetings done collaboratively should be based on al-Quran and the prophetic way of life in any activities and set their fate to Allah SWT so that the goals can be achieved. Apart from taking al-Quran and as-Sunnah as the 
way of life, four concept of Syura should be applied in organization. The principles are justice, brotherhood integrity, having solution in making decision and can generate competent work commitment based on the principle of Syura (Hasan Al-Banna et al., 2013).

To any top management that wants to protect and strengthen the organization quality management, they should not look down on matters regarding Syura because it can give huge contribution on total quality management and produce excellence service (Ilhaamie, 2002). According to Ilhaamie (2002), management must always meet employees to solve arising problem by helping each other and cooperate in welfare matters. With this, decision taken will be even and when implemented, can create sense of brotherhood among the employees and give motivation in every job they are supposed to do. Previous researchers have touched on the issue of Syura in quality management at a glance only. Additionally, the previous researchs were theoretical study only.

\subsubsection{Customer Focus}

Study conducted by Kutlu and Kadaifi (2014) and Mosadeghrad (2015) found that focus on customer is one of the factor in contributing to the effectiveness of quality management program. Harutyuyan et al. (2010) states that every customer have different perception and behavior on each services provided by an organizations. According to him, ages and customers education factor affect their overall acceptance on the service and level of satisfaction. Meanwhile, Azimatun et al. (2012) explained that management of organization should always periodically measure customer satisfaction to study on the effectiveness of the improvement process had been carried out.

Therefore, it is important that every organization provide quality and best product or service to achieve customer satisfaction. Because of that, management should take concern on the dimension most valued by customers in achieving their satisfaction on any services provided. These dimensions are reliability, assurance, tangible product, empathy and responsiveness (Johari, 2007). Study done by Liang and Zang (2009), found that quality service and customer satisfaction generally have positive relationship. Meanwhile, other study has found that customer satisfaction can affect the customer behavior to be positive, where customers are more incline to show loyalty towards any services by making repurchase or suggesting the service to others (Qin \& Prybutok, 2009).

Customer satisfaction is highly influenced by the customers desire to experience the best quality of service (Yusuf and Azlinda, 2011). Customer satisfaction towards an organization can be visualized as election when every voters will vote based on who provide the best quality. If one customer is not satisfied, usually they will move to other competitors that provide similar and having better service quality. Therefore it is important for an organization to provide maximum satisfaction to customers for the organization sustainability. Although customer focus issues have been studied by past researchers, the issue is discussed from an organizational factor perspective only. The studies are also conducted in manufacturing and administration organizations. The study of customer focus issues in Islamic administration institutions has never been conducted.

\subsubsection{Teamwork}

Study by Kutlu and Kadaifci (2014) found that the involvement of employees as among the factors that can make a quality management program to be successful. Meanwhile Melao and Gamboa (2012) had done a study in Portugal identified that employees involvement is a factor that influence the effectiveness of the implementation of quality management program. Involvement and participation employees have close relationship with teamwork. Teamwork can initiate emotion, innovation and thinking development towards product creation and creative services (Arsaythamby \& Kiew Hwee, 2012). Result of study by Wan Idrus and Maizatul (2012) found that employees give positive reaction and viewed that constructing a working team can stimulate the spirit of work among them. It also can stimulate the mind by having mixture of views and information among employees, facilitate change of ideas and also generate positive action and behavior among employees.

There are two main aspect in constructing quality working team which are bonding and building. Bonding can be created by activities such as family day, sports day, trips, recreation and many others. Besides that, building can be created through effective communication among working team (Wan Idros and Maizatul, 2012). Past studies on teamwork issues only examine the issue from the point of organizational factors affecting quality management. The studies did not examine teamwork issues from soft factors perspective.

\subsubsection{Reward and Appreciation}

Reward is a form of appreciation or benefits that is given from organization to employees on their good performance shown. Nearly all sectors in public and private organizations practice giving rewards (Azlina, 2013). Rewards and recognition is actually a way for organizations to show to employees that they are valuable to the management (De Lacy, 2009). Because of that, recognition and reward is seem as an important matter that can motivate employees behavior (Wilches, 2009).

Study by Chew and Chan (2008) shows that monetary rewards have positive relationship on the perception towards organizational support. Azmie (2006) proposed that, organizations have to provide a competitive and fair reward structure. The reward have to be worthy with the load and task complexity. When reward is paid based on the output of individual, they will be more competitive to increase their performance in organizational quality management. According to Md Lazim and Hadziroh (2015), the fair gift of rewards or wages is seemed to be a form of continuous recognition on the contribution of employees and as form of organizational support towards the positive behavior and attitude of employees.

Hasan Al-Banna et al. (2015) viewed that factor that can influence the implementation of quality management is a reward system that is implemented in an organization. This is according to them, reward system is an injection of encouragement to an employee to increase their overall organization performance. Reward also plays an important role and able to contribute to the effectiveness of organization. It can also give positive effect on employees' behavior and attitude (Farah Liyana et al., 2014). A manageable reward can increase the spirit of individual to work harder to achieve the aims and organizational strategy (Imran et al., 2014). Previous researchers examined reward and appreciation issues in the implementation of quality management from an organizational factor perspective. Additionally, past studies were conducted at administrative and manufacturing organizations. 


\subsubsection{Training and Development}

Training and development is an effort to give human skills that can help them in developing and expanding their overall potential and also maximum contribution towards organizations. Besides that, training functions as an improvement tool and also as an increment of current employees or individual in organization (Nadwatul \& Farah, 2014). Chidambaran and Ramachandran (2012) stated that training is a subprocess that matches an individual to their work through three main processes which are inspection, selection and placement.

Therefore, Anupa and Sumit (2011) stated that to ensure that training runs smoothly, an organization should analyze the need of training. According to them, this analysis is needed to identify the current level of skills, knowledge and individual attitude. It also serves as a need to know the level of skills and knowledge that is needed by an organization. This is consistent to the view by Sheeba (2011) and Anida (2016), that training that is given will not have a positive impact to organization if requirement analysis is not conducted.

Khanna et al. (2011), Kutlu and Kadaifci (2014), and Rajesh (2011) identified that training and education as factors that influence the success of the quality program implementation. Meanwhile, outcome of study by Mosadeghrad (2015) in health institution in Iran found that among the factors that make quality management program to be successful is training program. Mohamad Asrofi and Shahrizal (2016) and Hasan al-Banna (2015), viewed that employees quality training will determine the employees satisfaction which in turn will give impact to quality service delivered by the employees. Therefore, management should always proceed with proper training and ensuring the training bring impact to the organization. Apart from that, management must also increase the training budget to employees and it must be in line with the organization objectives. Previous studies on training and development issues in quality management only examine the issue from the perspective of success factors. A study that examines training and development from a soft factor perspective has never been carried out.

The analysis of the literature shows the six variables; the human factors which are the focus in this study are the variables that have never been studied in-depth by previous researchers. The previous studies on the six human factors that are top management leadership, Syura, customer focus, teamwork, reward and appreciation, and, training and development, only study these factors from an organizational and success factors perspective. An in-depth study that investigates at these six factors from the perspective of human factors has never been conducted. In addition, previous studies focused mainly on administrative and manufacturing entities. Studies on the human factors of the implementation of quality management programs in Islamic administrative institutions have never been conducted. Hence, there is a need to study about the human factors in the implementation of quality management programs in Islamic administrative institutions. This study is conducted at state level Islamic administrative institutions, namely the Selangor Islamic Religious Council.

\subsection{METHODOLOGY}

This qualitative study applies case study as the research strategy (Ormston et al., 2014), where it is suitable to be applied in assessing a phenomenon that is rarely occurred or new (Cepada and Martin, 2005). Case study chosen is MAIS, one of the Selangor state Islamic management, authorized in managing funds and baitulmal properties. Semi structured interview is used as the main method in data collection in this study to acquire clear and overall information from respondents.

Fifteen informants consisting top management and intermediate level officer has been interviewed on the soft factor implementation in quality management program implemented by MAIS. All interviewed directly and actively involved showed in Table 1. The informant's selection in this study was conducted using purposive sampling. According to Bernard et al. (2017), this sampling technique is very useful when a study population is special, unique and difficult to be found because. The informants are able to explain the real issue within the research scope to the researchers.

Braun and Clarke (2006) suggested that one method in analyzing data qualitatively is by thematic analysis. Therefore, researcher has been using thematic analysis as a way to analyze data in this study, by collecting data, constructing code, searching for themes and finally preparing the study report. In this study, the researcher has used the thematic analysis approach by recorded the findings of the interviews obtained, according to the methods and systems that have been determined. After that, the researcher constructs the outline of data that have been obtained, compared and classified the data into some section according to the predetermined objectives. Finally, the researcher has been built themes and special codes to facilitate and create interesting and quality reports. Theme that is being searched and constructed in this study is regarding soft factors in the implementation of quality management program in MAIS. Researchers also used data triangulation method to increase the findings credibility. Multiple source of data triangulation method was used by researchers for instance interview with respondents, researching in details on documents related to quality management in MAIS.

Table 1 Informant Demographics

\begin{tabular}{|l|l|l|l|}
\hline Nu & \multicolumn{1}{|c|}{ Position } & \multicolumn{1}{c|}{ Gender } & \multicolumn{1}{c|}{ Education } \\
\hline 1 & Assistant Quality assurance Officer & M & Degree Holder \\
\hline 2 & Assistant Principal Secretary & M & Degree Holder \\
\hline 3 & Public Relations Officer & M & Degree Holder \\
\hline 4 & Assistant Administrative Officer & M & Degree Holder \\
\hline 5 & Assistant Administrative & F & SPM \\
\hline 6 & Assistant Audit Manager & M & Degree Holder \\
\hline 7 & Assistant Audit Manager & M & Degree Holder \\
\hline 8 & Deputy Secretary & M & Degree Holder \\
\hline 9 & Quality Training Administrative Officer & M & Degree Holder \\
\hline 10 & Executive Assistant Research Division & F & Degree Holder \\
\hline 11 & Human Resources Assistant Manager & F & Degree Holder \\
\hline 12 & Human Resource Officer & F & Degree Holder \\
\hline 13 & Human Resource Officer & F & Degree Holder \\
\hline 14 & Corporate Liaison Officers & M & Degree Holder \\
\hline 15 & Corporate Liaison Officers & M & Degree Holder \\
\hline
\end{tabular}




\subsection{FINDINGS}

The research findings emerged from analysis shows that there are six human factors were practiced in quality management implementation in MAIS that are leadership, Syura (meeting), customer focus, teamwork, reward and appreciation, and, training and development. These human factors are explained as follows:

\subsection{Leadership}

The result shows that top management in MAIS always play their roles as leaders and involve directly in every program conducted by the organization especially programs based on quality management. Apart from that, leaders in MAIS always instill the awareness among employees that every action that comes from them must be following the desire of Allah SWT and the prophet p.b.u.h. According to the Head assistance of secretary, obedience is the first value that was instilled within the service performed within MAIS. Within this, one informant was interviewed and quoted as:

"The top management will always give reminders to the employees of MAIS that every work and action that we have done will be always under the watchful and monitors of Allah SWT Therefore, every employee of MAIS is recommended to protect the image of Islam and MAIS while protecting the behavior as officers at any time and places. In addition, top management always educates us so that we understand and be grateful of the joy that Allah has granted by translating it to carry the work with commitment and dedication".

The study result shows that top management of MAIS always monitor and help ignite ideas to increase the service and quality provided. Top management always physically presents with officers in discussing and meeting related to programs conducted on staff or society. This is in line with the views proposed by the Assistance Officer of Information Technology Center stating on the following:

"In the early stage, a special meeting to plan for quality programs was held together with the top management. Management always provides new ideas for every program that will be conducted. They will also ensure that every program concept must be suitable with quality of the activity that will be organized by MAIS. For example to form a spiritual and knowledgeable environment within staffs and officers of MAIS, top management has planned a special forum entitled MAIS ethics, where this activity has gathered a total of 200 staffs and officer of MAIS to give a clearer picture regarding ethics, vision, mission, objective motto and the authority in MAIS".

Apart from that, there result from the interview shows that several informants shows that the top management in MAIS not only involve in matters regarding policy or procedure only but also indirectly they play role in giving motivation and passion towards staff of MAIS. In this matter, the Deputy Secretary of MAIS was quoted as saying:

"Top management always gives motivation and concern regarding the condition of staffs in MAIS. The management concern on the responsibilities and work load handled by MAIS staff, they have formed a committee known as AKRAB where it functioned to help staff that needs help at workplace. Apart from that, top management has taken initiatives by organizing mentor mentee program involving 15 board members as mentor and mentee which consist of MAIS staff".

The Head of Secretary Assistance also stated that leaders in MAIS will not neglect in every work. Every problem or matter that cannot be solved by MAIS staff, the top management will help so any work can be expedited. Furthermore, top management always gives explanation regarding job scope regarding officers and staffs work so that they clearly understand the responsibilities and duties in the Islamic management institution. In this matter, one of the informants was quoted as saying:

\footnotetext{
"Before the management or leaders explain regarding job scope, the staffs will always try to fully understand the work and job they have to do. It can be seen when there is briefing session where MAIS staffs try to give clear picture on the job and responsibilities as officers and staffs of MAIS. Apart from that, at the beginning of the year, the management always holds a mass meeting with all MAIS work force to give reminders regarding their responsibilities and requirement to be obedient to the rules that have been stipulated".
}

\subsection{Training and Development}

Outcome from the interview with the officers shows that the work force is the most important asset to MAIS. Therefore, to accelerate in achieving the goal of MAIS, top management has organized continuous training program to increase workers skills. In this matter, the Quality Training Administrative Officer and the Deputy Secretary has explained the following:

"It is compulsory for all MAIS staff to attend training program for ten days in a year. Training program in MAIS is divided into two divisions which are core training where this training is given to staffs so that they can more understanding and in depth knowledge on their job scope. While, for general training is given within three days where they will be given the understanding regarding the Shari'ah law, Feqah, Tawheed and others". 
Public Relation Officer that was interviewed mentioned that training and quality division had conducted awareness briefing to all new and current staffs. Besides that, MAIS has constructed a documentation workshop whereby coaches have given briefing to new staff regarding desk files and work procedure manual (MPK). The Public Relation Officer has mentioned the following:

"As new staff, they have to follow all induction courses for six hours. In this induction, they will be introduced on all the divisions in MAIS and matters regarding ISO 9000, and awards that are need to be achieved. Apart from that, starting from this induction course, MAIS will give information regarding their importance and roles when they work in MAIS".

Another informant, assistance secretary of MAIS explained that, every department in MAIS has initiative in training their staffs in their own division. In this matter, some division in MAIS has undergone course and training to strengthen and empower the department management system. Among the courses and training provided were workshop on assessment of registration rules amendment, mualaf education, al-riqab staff team building, balanced scorecard laboratory program, understanding of managing MAIS property law and, mosque officer consolidation course.

Apart from that, few respondents that were interviewed mentioned that training conducted in MAIS has differences and unique from other organization. One of the program known as USRAH TAMRIN was created to increase the knowledge and understanding among the staffs toward Islam. This matter was explained by one of the officer in MAIS as the following:

"The TAMRIN program was conceptualized as usrah where officers of MAIS become the naqib and naqibah to the supporting staffs. Every meeting among the officers and staffs will be carried out by reading al-Quran and its translation, discussing on current issues and changing ideas and thought in solving work problem. TAMRIN was conducted to increase the understanding of staff related to al-Quran".

The Deputy Secretary of MAIS stated that officer and employee in MAIS were given training so that they have the expertise in planning, leading, decision making and problem solving. Training in MAIS is actually aims at increasing the performance of MAIS employees and to encourage staffs to be a person that is multi-tasking. Skilled and efficient employees can contribute in producing quality output for the organizations and community.

\subsection{Teamwork}

Teamwork is a way to unite whole members in an organization in succeeding quality management program. This spirit is practice through overall commitment and involvement of officers and staff quality enhancement programs implemented within the organization. The effort in implementing quality program cannot be cast upon individual due to the complexity in the work process and the involvement of several units. With that condition, everyone have to work within team so that every strength and resources within the organization can be utilized efficiently.

According to one of the quality assistance officer, quality programs conducted in MAIS need proper planning and implementation. Because of that, it needs cooperation and high commitment from all top management, officer and staff of MAIS. With that, to enhance teamwork culture, MAIS has taken initial steps by conducting programs that can enhance the relationship between officers and staffs of MAIS. This program is objectively constructed to increase the motivation to work in team, apart from diffusing an excellent work culture that can build efficient communication in accomplishing daily task. In this matter, one of the informants that was interviewed mentioned the following:

"Every year, management of MAIS conducted brotherhood concept program, MAIS and subsidiaries sports day. Occasionally, these programs were held externally for example in Cherengin Hill Convention \& Spa Resort. Various activities was held, among them are motivational talk, group activities, jungle trekking, football match, netball and many others. These programs aim to instill teamwork spirit among employees".

Outcome of the study shows that teamwork instilled in MAIS employees can reduce the gap between the top management, officers and support staff. It also can increase the awareness and responsibilities on the responsibilities. In this matter, one of the officer interviewed mentioned that team work can create positive values within each MAIS employees and ensuring employees to work collectively and complementing each other in fulfilling their responsibilities. This is consistent with the view given by the Public Relation Officer, as the following:

"It can be seen that every employees in MAIS are always communicating among each others to ensure that work can be completed smoothly. Staffs and officers always communicate, accomplishing task and plan together. With this, cooperation shown by MAIS employees can facilitate MAIS in achieving the predetermined goals".

Apart from that, according to the Information Technology Center Assistance Secretary, teamwork plays an important role in forming the work system of officer and staff of MAIS. When work system in MAIS is running smoothly, it is easy for MAIS to execute every program that has been planned. Also, it can stimulate initiative and creative behavior of employees in solving problems faced by MAIS customers in particular and the community in general. 


\subsection{Customer Focus}

Result from the study shows that, management have to take seriously in strengthening the relationship among the customers that uses MAIS service. Therefore, the first step taken by MAIS was finding the way to get to know their customer and the services needed. This initiative is meet the aim of the Deputy Secretary of MAIS, where the following view was:

"Actually MAIS need to know who are they dealing with, that is to work with the Muslim community and not for their own self. The Muslim look at what we are doing and they can take the benefits from the establishment of MAIS".

Officers that were interviewed explained that many activities and program had been done by MAIS to appreciate their customers. Among the well-known program conducted every year is customers open day and "JOM MAIS" carnival to approach the community. In this program, counters related to MAIS services were opened to be visited by the people. Apart from that, activities can strengthen the bonding among MAIS employees and people. Among the program were workforce peace, Save Gaza concert, MAIS chairman public speaking competition, Wakaf talk and many more. One of the informants was quoted as saying:

"Previous program was known as MAIS and subsidiaries customers' day, but now MAIS had organized this program in a bigger scale by involving other departments. The objective is to invoke the awareness of the community on the importance of MAIS role and its subsidiaries as the brand in Islamic institution that can be a stimulate in economy, social and human development".

Findings from the interview show that customer is one of the important assets for MAIS. It has become the responsibilities of the management and employees of MAIS to always maintain and further increase the customer's satisfaction in dealing with MAIS. Therefore, few respondents interviewed suggested that MAIS employees have to be fair and just to customers and provide the best service at any time. Employees are also reminded to fulfill their responsibilities with trust without any favorable and the most important is not influence by other parties. This is consistent with the view proposed by MAIS Head of Assistance Secretary, as the following:

"MAIS always remind every employee to avoid graft, misconduct and power abuse. The reason is, when these happen, it will create negative perception towards the institution, community and personal. MAIS employees also are reminded to execute their work and task without any personal preference and influence by other parties".

\subsection{Reward and Recognition}

Reward is an important aspect and as strategy used by organization to increase the quality of employees. Finding shows that, MAIS is not left behind in giving reward and recognition to its officers and staffs. According to several officers interviewed in MAIS, reward can be divided into two categories, formal and informal. In this matter, the Assistance Manager of Audit stated as follow:

"Formal reward normally is the same as other government agencies, only that it is tailored according to the need of MAIS. Formal reward is such as excellence employee award, medical insurance, work leave and promotion. While as informal reward include company trip in selected agencies within Malaysia, employees birthday celebration and employee's family day".

Findings from the interview show that management in MAIS promotes its employees to further their education at higher level. This encouragement tends to increase the competency by continuously empowering knowledge and skill. MAIS is seriously consider on increasing knowledge and skills because when MAIS employees have considerable knowledge, indirectly the employees will become role model that is known to the public and becoming people who have wise mind and conscience sensitivity. In this matter, one of the officer interviewed states the following:

"We encourage all MAIS employees to further studies. Those who further their studies, we will grant them full pay leave. At the moment there are two of our staff are on study leave doing PhD, while three staffs are on Master's Degree leave, while the rest are furthering their undergraduate degree".

According to the officer, reward and recognition given by MAIS is a fair concept and there is no favoritism among the employees due to the Islamic foundation as MAIS that have to be fair. It is needed to avoid the occurrence of unhealthy behavior such as flattering, bullying co-workers and others. Reward given is intended to reward and recognize MAIS employees for showing good work performance and high commitment in completing the task and responsibilities trusted upon them.

\subsection{Meeting (Syura)}

Syura or meeting is a mechanism of decision making that was practice by the Malays and Islam from the previous time. Syura is also an important element in an organization to acquire the best decision for an organization development. Findings from the study shows that MAIS had already pratic the Syura as a culture in making decision and making al-Quran and as-Sunnah as the main source in their decision making process. Every decision made by officer and staff of MAIS must be precise, clear, consistent and fair where the decision made must be consistent with the laws and regulations in MAIS. In this matter, one of the officer interviewed stated the following:

"As known, MAIS is one of the trusted Islamic bodies by the community in Selangor. Therefore, everything that is implemented cannot be done without full commitment, without considering the impact on Islam and community. 
Therefore, MAIS always conduct Syura or meeting to discuss programs or matters regarding MAIS service to the society so that it can be implemented properly and able to provide positive impact".

Staff at Information Technology Center that was interviewed stated that MAIS management also provide space and chance to every workforce to give their views through meetings that eventually give opportunity for them to implement the planned strategy by MAIS management. This is because, every activity or program that need to be implemented by MAIS division require clear and strong justification. By having discussion and meeting, MAIS would be able to avoid unfair decision making in every circumstance and able to ensure the smooth running of the pre-planned program.

Meanwhile, one of the MAIS officer stated that Syura is not only a normal meeting but it can contribute to the organization development and bring blessing and pleasure of Allah SWT. Syura implemented in MAIS has brought deep effect towards the decision made by MAIS. Apart from that, the practice of Syura in MAIS can train the employees to contribute and provide creative and innovative ideas in every discussion. Open minded, trusting and respecting one another in every work has become the culture in the discussion and meeting in MAIS.

\subsection{DISCUSSION}

Findings shows that there are six soft factors in the implementation of quality management program in MAIS which are top management leadership, training and development, team work, customer focus, Syura, reward and recognition. Main aim of the implementation of soft factor is to balance the material development and also increasing service quality provided in MAIS. This statement is in line with the view given by Law and Idris (2011) that soft factors can give positive and significant effect on the competitive market, profit, productivity, quality, human resource development, ability and capability of market development. Findings from this study also is closely related to the findings from Psomas et al. (2014) which found that soft factors give direct effect to the increment of quality, employee benefit and customer satisfaction.

MAIS is facing problem and challenges related to the behavior of officers and staffs in implementing quality management program. Initially, the implementation of quality program is rather difficult for the management to activate and call upon the officers and staff to involve in succeeding in the said program. This is due to the behavior of some of the employees that feel the quality program is just a side program and not the main aim that they should follow. This situation has raised the concern of the top management because quality management is one of the main success factors for any services. Therefore, one division of transformation plan under the organizational sector was created to realize the aim of MAIS transformation plan. The inception of MAIS transformation plan was introduced in the year 2011 whereby this plan was aimed at facilitating MAIS to move in a holistic way for implementing in the management and administration. Six important factors were focused on which are improvement, replacement, vibration, transformation, renewal and movement. All these can form the programs that can produce a successful environment in MAIS organization.

Therefore, in realizing MAIS agenda to run as planned, the findings shows that top management always play their role as leaders and directly involved in every activities and program implemented by the organization especially quality management programs. Finding is consistent with Kutlu and Kadaifci (2014), where leadership is an important factor that can ensure the success of quality program implementation. Apart from that, finding also suggested that management involve together by giving ideas to increase the quality of service in MAIS. This is consistent with previous study conducted by Hasan al-Banna (2015) and Zahrah et al. (2009) that management must always involve directly and give commitment to organizational success. This can be done by providing information to employees regarding the importance of quality management and its function, setting up the policy and quality objectives.

Apart from that, the findings shows that top management in MAIS did not neglect in every work that has to be done. Every problem or matter that cannot be solved by MAIS employees, top management will help so that every job that has been tasked on run smoothly. This initiative meet the view given by Nicholas et al. (2014), where leadership support towards quality management activities will produce conducive environment, competitiveness and continuous improvement.

Soft factors practice in MAIS also has reduced the gap between the top officers and staff, and increase the awareness and responsibilities on their roles. This can be proven every discussion and meeting regarding the management in MAIS, the top management will give space and chances to all the work force to give insight and giving way for the work force to together plan to increase implementation strategy in MAIS. Finding is closely related to the views of Muhammad Mustakim et al. (2015), that every decision maker must always collectively provided space to all parties in giving ideas before final decision is made.

Finding also shows that, al-Quran and as-Sunnah is the main source of reference in every decision made and implemented in MAIS. Apart from that, every decision made by officers and staffs of MAIS, is based on precision, clarity, fairness and based on the current regulation in MAIS. This is in line with the study by Hasan Al-Banna et al. (2013), that there are four principle in making decision (Syura) which are fairness, togetherness, brotherhood, having solution in making decision and generate competent work commitment.

Finding shows that implementation of soft factor covers aspect of training, education and self-development of work force in MAIS has able to increase the skills, knowledge and proactive attitude in realizing quality program implementation. Finding is closely related to the view of Nadwatyl and Farah (2014), that training can function to improve and increase the skills of current workers or individuals. Apart from that, from the author's view, every training conducted by MAIS is based on the current requirement of employees and the management has to improve and increase the quality of training program. This is consistent with the view of Anupa and Sumit (2011), to ensure that training run smoothly as planned, each organization must analyze on the individual level of skill, knowledge and attitude. If this has not been done, training will not give positive impact to the organization (Sheeba, 2011; Anida 2016).

Meanwhile, findings also show that team work is one of the way MAIS unite whole of the work force in the organization to ensure the effectiveness of quality management program. This is consistent with the study conducted by Melao and Gamboa (2012), that involvement of employees as team is the main factor that influences the successful of quality program implementation. Also, finding depicted that soft factor related to customer focus is an important factor in the effectiveness of quality management in MAIS. It can be proven when MAIS always strive to protect and increase customer satisfaction by giving good services, trustworthy and without favoritism, and not 
influence by other parties. Finding from this study coincide with study from Yusuf and Azlinda (2011), that customer satisfaction is deeply influence by customer desire to acquire the best quality service.

With respect to this, from detail research on soft factors conducted by MAIS are able to give positive impact on the implementation of quality management and the job scope of employees in the organization.

\subsection{CONCLUSION}

It can be concluded that soft factors is an important element in the implementation of quality management in MAIS. The implementation of quality management is focusing on soft factors which should be adopted by every government and private agencies, especially which are based on Islam. With soft factors considered in every organization, it can increase the competency of officers and staffs in realizing the effectiveness of the service offered. Quality management based on soft factors has helped MAIS in achieving the targeted objective which is to increase the social prosperity of the Muslim community in Selangor and delivering excellent services. Implementation of soft factor in MAIS also able to strengthen the brotherhood among employees, bridge the gap between high officers and support staff, increase the awareness and responsibility on the work trusted upon employees, create and practice team work culture, being open minded, enhance trust and respect in every action in the organization.

This study has contributed in knowledge development by adding soft factors in the quality management. This area is still lacking in the literature which are less touch by researchers. Apart from that, outcome of this study can give overall and in depth view regarding soft factors in quality management in the context of Islamic management institution. This kind of study is still lack within the literature by previous studies. This study is qualitative, therefore future researchers can do a quantitative study. Other aspects can be looked into such as the aspect of work culture that can affect the implementation of organization program within the public and private sector.

\section{References}

Abdullah Ahmad Qadiri, (2012), Syura prinsip Utama Sistem Pemerintahan Islam, Al-Hidayah Publisher: Kuala Lumpur.

Ahmet Can Kutlu, Cigdem Kadaifci, (2014) "Analyzing Critical Success Factors Of Total Quality Management By Using Fuzzy Cognitive Mapping", Journal of Enterprise Information Management, 27(5), 561-575.

Ali Mohammad Mosadeghrad, (2015) "Developing And Validating A Total Quality Management Model For Healthcare Organisations", The TQM Journal, 27(5), 544564 .

Anida Ismail, (2016), "Merancang Proses Menentukan Kumpulan Latihan Bagi Staf Akademik Kolej Profesional MARA", Ulum Islamiyyah Journal, 17(June), 21-42. António Jorge Gamboa, Nuno Filipe Melão, (2012) "The Impacts And Success Factors of ISO 9001 In Education: Experiences From Portuguese Vocational Schools", International Journal of Quality \& Reliability Management, 29(4), 384-401.

António Jorge Gamboa, Nuno Filipe Melão, (2012) "The Impacts And Success Factors of ISO 9001 in Education: Experiences From Portuguese Vocational Schools", International Journal of Quality \& Reliability Management, 29(4), 384-401.

Anupa Chaudhary and Sumit Prasad (2011), "Training for Development of Professional Education", International Journal of Innovation, Management and Technology, 2(2), 162-165.

Arsaythamby Veloo., dan Kiew Hwee Bin, (2012), Hubungan Antara Kerja Berpasukan Dengan Kepuasan Kerja Ketua Panitia Sekolah Menengah, IJMS, 19(1), 175191.

Azimatun NA, Salmiah B dan Ahamad J., (2012), Kajian Keratas Rentas Perbandingan Kepuasan Pelanggan di Antara Klinik-Klinik Kesihatan Primer Luar Bandar dan

Bandar di Daerah Hulu Langat dan Faktor-Faktor Yang Mempengaruhi, Malaysian Journal of Public Health Medicine, 12(2), 52-67.

Azlinda Binti Jaini., (2013) A Study On The Factors That Influence Employees Job Satisfaction At Scope International (M) Sdn. Bhd. Uitm Shah Alam: Disertasi. Sarjana.

Azmie., (2006), Sepakat Daripada Perspektif Pengurusan Organisasi, Utusan Publications \& Distributors: Kuala Lumpur.

Braun, V., and Clarke, V., (2006), "Using Thematic Analysis In Psychology”, Qualitative Research in Psychology, 3(2), 77-101.

Cepada and Martin, (2005), "A Review of Case Studies Publishing in Management Decision 2003-2004", Management Decision, 43(6), 851-876.

Chew, J., \& Chan, C. C. A., (2008). Human Resource Practices, Organizational Commitment and Intention to Stay, International Journal of Manpower, 29(6), 503522 .

Chidambaram, V., \& Ramachandran, A., (2012). A Study on Efficacy of Employee Training: Review of Literature. Business: Theory and Practice/Verslas", Teorija ir Praktika, 13(3), 275-282.

Corredor, P. and Goni, S., (2010), “Quality Awards and Performance: Is There A Relationship?” The TQM Journal, 22(5), 529-538.

Daniel I. Prajogo, Christopher M. McDermott., (2005), "The Relationship Between Total Quality Management Practices And Organizational Culture", International Journal of Operations \& Production Management, 25(11), 1101-1122.

David Gadenne and Bishnu Sharma, (2009), An Investigation Of The Hard And Soft Quality Management Factors of Australian SMEs and Their Association With Firm Performance, International Journal of Quality \& Reliability Management, 26(9), 865 - 880.

De Lacy, J.C., (2009), Employee Engagement: The Development of a Three Dimensional Model of Engagement; and an Exploration of its Relationship with Affective Leader Behaviors, School of Management, Queensland University of Technology, Brisbane.

Drew, E. and Healy, C. (2006), "Quality Management Approaches in Irish Organizations", The TQM Magazine, 18(4), 358-71.

Farah Liyana B, Teng SS, Fakhrul Zaman A., (2014), "Reward Management and Job Satisfaction Among Frontline Employees In Hotel Industry in Malaysia," ProcediaSocial and Behavioral Sciences, 144, 392-402.

Flyn, D.B., Schroeder, R.G., \& Sakakibera, S., (1995), “The Impact of Quality Practices on Performance and Competitive Advantage”, Decision Sciences, 26(5), 659691.

Fotopoulus C.B, and Psomos E.L., (2009), “The Impact of Soft and Hard TQM Elements on Quality Management Results”, International Journal of Quality \& Reliability Management, 26(2), 150-163.

H.Russel Bernard, Amber Wutich, Gery W.Ryan., (2017), Analyzing Qualitative Data, Systematic Approaches, SAGE Publications: Singapore.

Hafeez, K., Malaka, N. and Abdelmeguid, H., (2006), "A Framework for TQM to Achieve Business Excellence", Total Ouality Management, 17(9), 1213-29.

Harjeev K. Khanna, D.D. Sharma, S.C. Laroiya, (2011) "Identifying and Ranking Critical Success Factors For Implementation of Total Quality Management in the Indian Manufacturing Industry using TOPSIS", Asian Journal on Quality, 12(1), 124-138.

Harutyunyan T, Demirchyan A, Thompson ME, Petrosyan V., (2010), "Patient Satisfaction With Primary Care In Armenia: Good Rating Of Bad Services?", Health Services Management Research, 23, 12-17.

Hasan al-Banna Mohamed, Ab. Mumin Ab Ghani dan Siti Arni Basir., (2013), "Sistem Pengurusan Islam Yang Berkualiti Mampu Menjamin Kepuasan Pekerja: Suatu Realiti dan Cabaran Masa Hadapan", GJAT, 3(1), 67-84. 
Hasan al-Banna., (2015), "Kajian Kes Pelaksanaan MS 1900:2005 Sistem Pengurusan Kualiti Menurut Perspektif Islam di Institusi Pengajian Tinggi Malaysia, Tesis Jabatan Syariah dan Pengurusan, Universiti Malaya.

Hasliza Mohamad Ali, Siti Arni Basir and Musaiyadah Ahmadun., (2016), "Implementation of the Islamic Quality Management System MS 1900 and its Benefits: A Case Study at the Department of Hajj, Waqf and Zakah, Malaysia”, GJAT, 6(2), 85-98.

Hayati Habibah Abdul Talib, Khairul Anuar Mohd Ali, Fazli Idris, (2014) "Critical Success Factors Of Quality Management Practices Among Smes In The Food Processing Industry in Malaysia", Journal of Small Business and Enterprise Development, 21(1), 152-176.

Ho, D.C.K., Duffy, V.G. and Shih, H.M. (2001), “Total Quality Management: An Empirical Test For Mediation Effect”, International Journal of Production Research, 39(3), 529-548.

Hoang, D.T., Igel, B. and Laosirihongthong, T. (2006), "The Impact of Total Quality Management on Innovation. Findings from a Developing Country", International Journal of Quality \& Realibility Managemenet, 23(9), 1092-117.

Ilhaamie Abdul Ghani Azmi., (2002), "Pengurusan Kualiti Menyeluruh (TQM), Satu Perbandingan Antara Konvensional dan Islam”, Jurnal Syariah, 10(2), 67-86.

Imran A, Ahmad S, Nisar AQ, Ahmad U., (2014), "Exploring Relationship Among Rewards, Recognition And Employees' Job Satisfaction: A Descriptive Study On Libraries in Pakistan". Middle-East Journal of Scientific Research, 21(9), 1533-1540.

Johari, R,. (2007), "Identifying What Services Need To Be Improved By Measuring The Library Performance", Malaysian Journal Of Library And Information Science, $12,35-53$.

Khanna K.H., and D.D. Sharma., (2011), "Identifying and Ranking Critical Succes Factors for Implementation of Total Quality Management in the Indian Manufacturing Industry Using TOPSIS", Asian Journal on Quality, 12(1), 124-138.

Lau dan Idris., (2001), "The Soft Foundation Of The Critical Success Factors in TQM Implementation in Malaysia", The TQM Magazine, 13(1), 51-62.

Lewis, W.G., Pun, K.F. and Lalla, T.R.M. (2006a), "Exploring Soft Versus hard Factors for TQM Implementation in Small and Medium-Sized Enterprises", International Journal of Productivity and Performance Management, 55(7), 539-54.

Lewis, W.G., Pun, K.F. and Lalla, T.R.M. (2006b), "Empirical Investigation of the Hard and Soft Criteria of TQM in ISO 9001 Certified Small and Medium-Sized Enterprises", The International Journal of Quality \& Reliability Management, 23(8), 964-85.

Liang, X. and Zhang, S. (2009), "Investigation of Customer Satisfaction In Student Food Service: An Example of Student Cafeteria in NHH", International Journal of Quality and Service Sciences, 1(1), 113-124.

Ligabue, S. (2009), “The Role Of Assessment And Evaluation In Training Human Relations Professionals", Transactional Analysis Journal, 39(4), 315-319.

Madi, M.A., Jegak, U., and Tari J.J., (2008), The Influence of Soft Factors on Quality Improvement and Performance, Perception from Managers, The TQM Journal, 20(5), 436-452

MAIS (2015), RM 21.2 Juta untuk Pendidikan dan Pembangunan Muallaf, http://www.mais.gov.my/info-mais/informasi/mais-media/259-rm21-2-juta-untukpendidikan-dan-perkembangan-muallaf.

Md Lazim Mohd Zin dan Hadziroh Ibrahim., (2015), "Hubungan Antara gaya Kepimpinan dan Ganjaran Kewangan dengan Persepsi Terhadap Sokongan Organisasi", Journal of Business and Social Development, 3(1), 12-24.

Melao N., and Gamboa J.A., (2012), "The Impacts and Success Factors of ISO 9001 in Education: Experiencess from Portuguese Vocational Schools", International Journal of Quality \& Reliability Management, 29(4), 384-401.

Mohamad Asrofi Muslim., dan Shahrizal Badlishah., (2016), "Hubungan di antara Latihan dan Motivasi Terhadap Kepuasan Kerja: kajian Kes di Pusat Latihan Pengajaran dan Kemahiran Lanjutan (CIAST), Shah Alam", Skills Malaysia Journal, 2(1), 11-26.

Mohamed Sani. I. \& Mumtaz Begum A.K. (t.t.). Integriti Kepimpinan dan Pengurusan Kualiti Menyeluruh (TQM) Dimensi Kemanusiaan Terhadap Iklim Proses Organisasi: Satu Kajian Kes, Bangi: Universiti Kebangsaan Malaysia.

Mora A.C, Picón A., Ruiz. C., and Cauzo, L., (2013), "The Relationships Between Soft-Hard TQM Factors and Key Business Results , International Journal of Operations \& Production Management, 34(1), 115 - 143.

Muhammad Mustakim Mohamed Noh, Siti Arni Basir, Lukhman Taib, Musaiyadah Ahmadun dan Wan Norhasniah Wan Husin., (2015), "Kajian Kes Perlaksanaan Etika Kerja Islam (EKI) di Johor Corporation (JCorp): Tumpuan Kepada Perlaksanaan dan Faedahnya", Jurnal Pengurusan, 45, 105-118.

Mumtaz Begam, A.K., Norzaini, A., dan Mohamed Saini, I., (2010), "Pengaruh Integriti Kepimpinan Terhadap Pelaksanaan Pengurusan Kualiti Menyeluruh di Institusi Pendidikan Tinggi MARA", Akademia, 78, (Jan-April), 67-75.

Nadwatul Husna dan Farah (2014), "Hubungan Antara Sumber Manusia Dengan Niat Kakitangan Akademik Untuk Terus Kekal di Universiti Swasta", ICSSR,. 885897.

Nektarios Oraidpoulos (2015), "Resource Allocation Decision Under Imperfect Evaluation and Organizational Dynamics”, Management Science, 61(9), 2139-2159.

Nicholas Kingsley Graham., Yarhands Dissou., Arthur Duke., and Peprah Mensah , (2014)," Managerial Role In Ensuring Successful Total Quality Management Programme In Ghanaian Printing Firms ", The TQM Journal, 26(5), 398 - 410.

Oakland J.S, (2004), Quality Management, Burlington: Elsevier Butterwoth Heinemann.

Oakland J.S. (2009). Ke Arah Peningkatan Prestasi Pengurusan Kualiti Menyeluruh (Abdul Rahman Ibrahim). Kuala Lumpur: Terjemahan Negara Malaysia.

Ormston et al., (2014), "The Foundations of Qualitative Research" dalam Qualitative Practice: A Guide for Social Science Student and Researchers, eds. Ritchie, J. Lewis, J., Nicholls, C.M dan Omrston, R., $2^{\text {nd }}$ edition, Los Angeles: Sage Publication.

Prajogo, D.I. (2005), "The comparative analysis of TQM practices and quality performance between manufacturing and service firms", International Journal of Service Industry Management, 16(3), 217-22.

Psomas, E., Vouzas, F., Kafetzopoulos, D., (2014)," Quality Management Benefits Through the "Soft" and "Hard" Aspect of TQM in Food Companies ", The TQM Journal, 26(5), 431-444.

Qin, H. and Prybutok, V.R. (2009), "Service Quality, Customer Satisfaction, and Behavioral Intentions in Fast-Food Restaurants", International Journal of Quality and Service Sciences, 1(1), 78-95.

Rahman, S. (2001), “A Comparative Study of TQM Practice and Organizational Performance of SMEs with and Without ISO Certification”, International Journal of Quality \& Reliability Management, 18(1), 35-49.

Rahman, S. (2004), “The Future of TQM is Past. Can TQM be Resurrected?", Total Quality Management, 125(4), 411-22.

Rahman, S. and Bullock, P. (2005), "Soft TQM, Hard TQM and Organizational Performance Relationship: an Empirical Investigation", Omega, 33 (1), 73-83.

Rajesh Kr Singh, (2011) "Analyzing the Interaction of Factors for Success of Total Quality Management in SMEs", Asian Journal on Quality, 12(1), 6-19.

Roslina Ab. Wahid (2006). Quality management: Principles, Systems and Tools, Shah Alam: Upena.

Sheeba Hamid (2011), "A Study of Effectiveness of Training and Development Programs of UPSTDC, India-An Analysis", South Asian Journal of Tourism and Heritage, 4(1), 72-81.

Sila, I. and Ebrahimpour, M. (2005), "Critical Linkages Among TQM Factors and Business Results", International Journal of Operations \& Production Management, 25(11), 1123-55

Siti Arni Basir, Ilhaamie Abd Ghani Azmi dan Nor 'Azzah Kamri. (2013). Sistem Pengurusan Kualiti Islam MS 1900 Sebagai Program Inovasi Pentadbiran Awam: Kajian Kes di Pusat Zakat Melaka (PZM). Prosiding Seminar Inovasi Sektor Awam Peringkat Kebangsaan 2013. Anjuran bersama Institut Tadbiran Awam Negara (INTAN) dan Pusat Inovasi dan Produktiviti Pentadbiran Awam (PIPA), USM. Pulau Pinang. 18-19 November 2013, 62-71.

Siti Arni, B., Hassan, A.B., Sharifah Hayaati, S.I., Ilhaamie, A.G.A., Musaiyadah, A. (2016). "Integrating Soft (insanyyiah) Factors in Quality Management System ISO 9000 Implementation". Journal of Usuluddin, 43, 137-170.

Srikanthan, G. and Dalrymple, J.F., (2003), "Developing Alternative Perspectives for Quality in Higher Education". The International Journal of Educational Management, 17(3), 126-136.

Sun H., Hui, I.K., Tam, A.Y.K. \& Frick, J (2004), "The Trajectory of Implementing ISO 9000 Standard Versus TQM in Western Europe", International Journal of Quality and Reliability Management 1(2), 131-153.

Syed Azauddin S.B (2005), Alternative Quality management Standard Islamic Perspective, Kuala:Lumpur.

Syed Othman al-Habshi (1998), Pengurusan dan Pentadbiran Satu Gagasan, IKIM: Kuala Lumpur. 
Thiagaragan, T., Zairi, M., \& Dale, B.G., (2001). A Proposed Model of TQM Implementation Based on an Empirical Study of Malaysian Industry, International Journal of Quality \& Realibility Management, 18(3), 289-306.

Vouzas, F. \& Psyhogios, A.G. (2007). "Assessing Managers Awareness of TQM", The TQM Magazine, 19(1), 62-75.

Wan Idros dan Maizatul Haizan (2012), "Analisis Keberkesanan Pembinaan Pasukan (Team Building): Impak Ke Atas Sumber Daya Manusia”, Jurnal Komunikasi, 28(2), 227-241.

Wilches-Alzate, G. (2009), “The Relationship Between Rewards And Recognition, Service-Oriented Organizational Citizenship Behaviour, And Customer Satisfaction”, Unpublished thesis, Waterloo, Ontario.

Yang C.C. (2006), "The Impact of Human Resource Management Practices on the Implementation of Total Quality Management", The TQM Magazine, 18(2), 162-73.

Yusof Boon dan Azlinda Kasma., (2011), "Kepuasan Pelanggan Fakulti Pendidikan UTM Terhadap Kualiti Perkhidmatan di Pusat Kesihatan UTM, Journal of Educational Management, 1, 103-120.

Zahrah Hassan, Abu Daud Silong dan Nazri Muslim., (2009), “Kepimpinan Beretika dan Kecemerlangan Organisasi dalam Perkhidmatan Awam”, MALIM, $10,39-52$. 